Aquaculture

November 2015, Volume 448, Pages 521-530

http://dx.doi.org/10.1016/j.aquaculture.2015.06.019

http://archimer.ifremer.fr/doc/00271/38244/

(c) 2015 Elsevier B.V. All rights reserved.

\title{
Can survival of European flat oysters following experimental infection with Bonamia ostreae be predicted using QTLs?
}

\author{
Harrang Estelle ${ }^{1,{ }^{*}}$, Heurtebise Serge ${ }^{1}$, Faury Nicole ${ }^{1}$, Robert Maeva ${ }^{1}$, Arzul Isabelle ${ }^{1}$, \\ Lapègue Sylvie $^{1}$
}

${ }^{1}$ Ifremer, SG2M-LGPMM, Laboratoire de Génétique et Pathologie des Mollusques Marins, Avenue de Mus de Loup 17390 La Tremblade, France

* Corresponding author : Estelle Harrang, email address : estelle@harrang.fr

\begin{abstract}
:
The present study identifies quantitative trait loci (QTLs) in response to an experimental infection with the parasite responsible for bonamiosis, Bonamia ostreae, in two segregating families of the European flat oyster, Ostrea edulis. We first constructed a genetic-linkage map for each studied family and improved the existing genetic-linkage map for the European flat oyster with a set of SNP markers. This latter map now combines the best accuracy and the best estimate of the genome coverage available for an oyster species. Secondly, by comparing the QTLs detected in this study with those previously published for $O$. edulis in similar experimental conditions, we identified several potential QTLs that were identical between the different families, and also new specific QTLs. We also detected, within the confidence interval of several QTL regions, some previously predicted candidate genes differentially expressed during an infection with $B$. ostreae, providing new candidate genome regions which should now be studied more specifically.
\end{abstract}

\section{Highlights}

- The present study improved the previously published genetic-linkage map for the European flat oyster with a set of SNP markers to give the best genome coverage map for an oyster species. Several quantitative trait loci (QTLs) in response to an experimental infection with Bonamia ostreae, the parasite responsible for bonamiosis, were identified in two new segregating families of Ostrea edulis. We found a concordance in the localization of previously identified candidate genes differentially expressed during an infection with $B$. ostreae and the QTLs detected in the two analysed families, providing candidate genome regions which should be studied more specifically for Marker-Assisted Selection (MAS) programs.

Keywords: Ostrea edulis, Single Nucleotide Polymorphism, disease resistance, genetic and QTL mapping, candidate genes 


\section{INTRODUCTION}

The European flat oyster Ostrea edulis is native to European coasts. Its geographic distribution area extends from the North Sea to the Atlantic coast of the Iberian Peninsula and includes the Mediterranean Sea and Black Sea (Ranson, 1967; Jaziri, 1990). The species has also been introduced to the United States and Canada (Vercaemer et al., 2006) for aquaculture, although most $O$. edulis populations are located in Europe. Since the 1970s, its European production has drastically decreased due to the emergence of two protozoan diseases: marteiliosis, caused by Marteilia refringens, and bonamiosis, caused by Bonamia ostreae. Nevertheless, the European flat oyster still remains an important economic species (2300 t, 21.4 million USD; FAO, 2011). Like all other marine bivalves, it has two specificities that limit its means to fight disease: (1) it grows in an open environment that cannot be protected, and (2) it possesses an innate immune system that has no adaptive response, making the use of vaccines impossible. In recent decades, new management practices (e.g. oyster culture in deep water) have made it possible to avoid marteiliosis-related mortalities, but do not provide an efficient means to counter bonamiosis. To restore European flat oyster culture, the selection of animals naturally resistant to bonamiosis is therefore a very promising approach.

Selective breeding programs for animals resistant to mortality induced by $B$. ostreae have been developed in France and Ireland (Martin et al., 1992; Baud et al., 1997; Naciri-Graven et al., 1998; Culloty et al., 2001). In France, an experimental breeding program initiated by Ifremer in 1985 demonstrated that it was possible to improve the survival of oysters (Naciri-Graven et al., 1998) and to reduce infestation by the parasite (Martin et al., 1992). However, a decline in Bonamia tolerance was demonstrated within a few generations of selection. This phenomenon was attributed to a drastic reduction in genetic diversity, but also to a potential accumulation of deleterious alleles over the generations (Launey et al., 2001). To restore a sufficient level of genetic diversity for continued selective breeding, the subsequent crosses were reoriented to follow an intra-familial selection scheme (Bédier et al., 2001). The newly-produced families were issued from crosses among selected strains and showed enhanced survival and lower prevalence of the parasite (Bédier et al., 2001). These studies identified components of the genetic basis of the resistance to the 
infection by $B$. ostreae.

Lines of $O$. edulis resistant to bonamiosis could contribute to the sustainable production of this oyster species. To produce such lines it is essential to enhance genetic improvement programs by direct selection on genes or genomic regions affecting economic traits (Dekkers, 2004); in this case, the resistance against the intrahaemocytic parasite Bonamia ostreae. The identification and mapping of such genomic regions is commonly performed by a QTL (Quantitative Trait Loci) method. This approach uses genetic marker association and different statistical methods to study phenotypes to identify and delimit genomic regions where putative genes responsible for traits of interest are located. The genomic regions thus identified may provide valuable information and tools for Marker-Assisted Selection (MAS), so as to accelerate the selective breeding process and remove the need for disease exposure as a selection method.

In order to identify QTL regions linked to a phenotype of interest, it is essential to have a genetic linkage map for the studied species. However, in non-model species like the European flat oyster, for which a whole genome sequencing project has not yet been performed, a reference genetic linkage map is usually not available and the number of molecular markers is relatively limited. An alternative method consists in the construction of a genetic linkage map with the largest density of molecular markers possible, to maximize the genome coverage, for each studied segregating family (Vignal et al., 2002). In marine bivalve species of aquacultural interest, identification and localization of QTLs on these low density genetic maps has been done for the Zhikong scallop Chlamys farreri (Zhan et al., 2009), hermaphroditic bay scallop Argopecten irradians (Qin et al., 2007; Li et al., 2012), Eastern oyster Crassostrea virginica (Yu and Guo, 2006), Pacific oyster Crassostrea gigas (e.g. Sauvage et al., 2010; Guo et al., 2012) and European flat oyster O. edulis (Lallias et al., 2009). For $O$. edulis, 10 linkage groups are expected, to match the haploid chromosome number (Thiriot-Quiévreux and Ayraud, 1982).

A previous study on $O$. edulis identified a total of 5 QTLs for resistance to $B$. ostreae; these were detected in one segregating family after a cohabitation experiment. However, these QTLs could not be directly used in a MAS program because the genomic regions identified contained hundreds of genes and, to optimize the 
efficiency of the breeding program, it is necessary to reduce the confidence interval (Spelman and van Arendonk, 1997). Moreover, it was also necessary not only to test other genetic backgrounds to confirm the position of QTL regions previously detected, but also to detect potential new QTLs that did not segregate in the family studied by Lallias et al. (2009). Finally markers were also needed that were more easily transferable among populations and laboratories than the AFLPs previously used.

The present study aimed to identify QTLs in response to an infection with the parasite $B$. ostreae in two segregating families of $O$. edulis. Individuals from two flat oyster families were reared in contact with wild oysters experimentally over-infected with $B$. ostreae over one year. This infection method enabled us to mimic the spread of the parasite in the natural environment. QTLs were then identified for two phenotypes: survival/mortality and parasite load. We studied the third generation $\left(F_{2}\right)$ of each pedigree in order to know linkage phase of segregating variants. As the grandparents are from different origins (wild or selected), this segregation made it possible to identify the wild or selected origin of QTL alleles. QTLs identified were then compared between the two segregating families and with QTLs previously obtained under similar experimental conditions (Lallias et al., 2009). The previously published parental maps were mainly constituted of AFLP markers (85.7-87.4\% of mapped markers). To facilitate transferability, we tested a new set of SNP markers specifically developed for the European flat oyster (Lapègue et al., 2014). These new molecular markers were used to construct the linkage maps of the new tested families and were also added to the QTL map published by Lallias et al. (2009). 


\section{MATERIAL AND METHODS}

\subsection{Segregating families}

We used two different three-generation families initiated in 2003 and 2004. First, we crossed one wild-type oyster (W31 or W120) with an oyster from one of the selected families from the Ifremer selective breeding program against bonamiosis (703-29) or from an inbred line that had shown good resistance to bonamiosis (L002-55) to produce two $F_{1}$ biparental families OE. $F_{1} .04 .10$ and OE.WL.03.30, respectively. Then, in 2009, two full-sibs from each $F_{1}$ family (04.10-7 and 04.10-15 for Family 1; 03.30-1 and 03.30-6 for Family 2) were crossed to produce $F_{2}$ segregating families (Family 1: OE. $F_{2} .09 .04$; Family 2: OE. $F_{2} .09 .67$, respectively). All crosses were performed as described in Lallias et al. (2007). The new $F_{2}$ families were named according to the existing system. For example, OE. $F_{2} .09 .04$ refers to a $F_{2}$ family of $O$. edulis produced in 2009 as batch number 04.

The individuals from the two $F_{2}$ families (referred to hereafter as the tested oysters) were produced in the same environmental conditions, and were also naive to bonamiosis (no prior contact). These two families will be referred to hereafter as Family 1 and Family 2 , respectively.

\subsection{Experimentally-induced bonamiosis infection}

As there is no known means to cultivate $B$. ostreae, naturally infected wild $O$. edulis collected in the Bay of Quiberon (Southern Brittany, France), an endemic zone for bonamiosis, were used to purify the parasite. Then, four-year-old wild oysters, collected in the same natural area and potentially already infected with $B$. ostreae, were injected with the purified suspension of parasites in order to over-infect them.

The parasite was purified according to Mialhe et al. (1988). The amount of purified parasites obtained enabled the injection of a $100 \mu \mathrm{l}$ suspension of $1 \times 10^{6}$ parasites into the adductor muscle of 300 wild oysters, to be used as donors in the experiment. This procedure was performed on oysters previously anesthetized with $\mathrm{MgCl}_{2}$, using a $1 \mathrm{~mL}$ syringe fitted with a $23 \mathrm{G}$ needle $(0.6 \times 25 \mathrm{~mm})$.

The experimental design consisted of 6 150-L tanks, each containing 4 trays; the top and the third trays in each stack contained 25 donors, and the second and the fourth trays contained 50 tested oysters, that can be considered as recipients. Each tank 
contained oysters from one family only, so three tanks per family were used. A total of 50 donors and 100 recipients per tank were used, except for the last tank of Family 2 for which only 50 recipients were still available. At the beginning of the experiment, the recipients were 1 year old. As the oysters were very small it was not possible to identify each of them as a member of one or the other family, which is why the families were kept in separate tanks. The difference in size between donors and recipients has enabled to distinguish them in the tanks along the experiment.

The cohabitation experiment was run over 15 months from April 2010 to July 2011. During the experimental period, each tank was supplied with phytoplankton-enriched seawater at 60 L.h ${ }^{-1}$. Mortality was monitored daily as described in Lallias et al. $(2008,2009)$ and dead oysters were removed. To balance the parasitic pressure over all tanks despite these deaths, the number of injected wild oysters was systematically re-adjusted between the tanks. For tested oysters, samples of tissue were collected from each dead individual for further analysis. At the end of the experiment, all remaining oysters from both families were sacrificed and tissue samples collected.

\subsection{DNA extraction and parasite load}

For each tested family, genomic DNA from dead and sacrificed individuals was extracted from $20 \mathrm{mg}$ of gill tissue using a QIAamp DNA mini-kit (Qiagen) according to the manufacturer's instructions. Quality and concentration were assessed on a $2 \%$ agarose gel and a NanoDrop Spectrophotometer ND-2000 (Thermo Scientific). Concentrations were equilibrated to $100 \mathrm{ng} \cdot \mathrm{\mu L}^{-1}$ per DNA sample.

For each tested oyster, the level of parasitic infection was assessed by real-time PCR using primers targeting one of the $B$. ostreae actin 1 genes according to Robert et al. (2009). All reactions were carried out in triplicate in $25 \mu \mathrm{L}$, comprising $5 \mu \mathrm{L}$ genomic DNA at 5 ng. $\mathrm{LL}^{-1}$ (sample) or plasmid DNA (positive control) or distilled water (negative control). Data were collected with MxPro software (Stratagene). Replicates of the same sample were validated if the $\mathrm{Ct}$ values ranged between $[-0.5 \mathrm{Ct}$; $+0.5 \mathrm{Ct}$. The number of $B$. ostreae actin gene copies per sample was assessed by comparing the Ct value obtained for each sample (mean of triplicates) with the standard curve 
prepared with serial dilution of plasmid DNA.

\subsection{Genotyping}

Each mapping family consisted of two grandparents $\left(F_{0}\right)$, two parents $\left(F_{1}\right)$ and the progeny $\left(F_{2}\right)$. Given the low volume and low concentration of extracted DNA available for analysis, the genomic DNA of the four $F_{0}$ was amplified with an IllustraTM GenomiPhi ${ }^{T M}$ V2 Amplification Kit (GE Healthcare) according to the manufacturer's instructions.

A set of 384 SNP markers, specifically developed for European flat oyster (Lapègue et al., 2014) from direct sequencing (Harrang et al. 2013) and in silico screening from NGS sequencing (Cahais et al. 2012), has already been developed. GoldenGate genotyping with VeraCode Technology (Illumina Inc., San Diego, CA, USA) was performed according to the manufacturer's instructions. Clustering was realized using the GenomeStudio software package (Illumina Inc.). Reliability of SNP detection and coding were the same as described in Lapègue et al. (2014).

\subsection{Linkage mapping}

A genetic linkage map was built independently for each of the $F_{2}$ families, using JoinMap $^{\circledR} 4$ (van Ooijen, 2006). The type of segregation at each locus was determined prior to coding the genotypes according to population type (here "Outbreeder full-sib family"). Then, the first step in the mapping was to test the segregation distortion of each locus against normal Mendelian expectation ratios with a normal classification of genotypes, using the Chi-square test (van Ooijen, 2006). The second step was to calculate linkage between each pair of markers, using the independence LOD (Logarithm of the Odds Ratio, Morton, 1955) score for the recombination frequency. A LOD score higher than 3.0 was considered as significant and enabled the grouping of markers into linkage groups (LG). Next, genetic distances were calculated using the method of Kosambi (1944), and the most likely order of markers was determined using permutations. For each order, the corresponding goodness-of-fit (a $\mathrm{G}^{2}$ likelihood ratio statistic) was calculated. The expected length of the genome was then estimated using method 4 of Chakravarti et 
al. (1991). Genome coverage was then estimated by calculating the ratio of the observed genome length (sum of the length of all LG) to the expected length.

Additionally, as extracted DNA samples were still available for the 96 individuals (92 $F_{2}, 2 F_{1}$ and $2 F_{0}$ ) of the family used for the previous QTL detection experiment (Lallias et al., 2009), the 384 SNPs were also genotyped in those individuals and mapped in this family. An updated genetic map was built for this family with the three different types of genetic marker: AFLPs, microsatellites and SNPs. This is referred to hereafter as the completed genetic linkage map of Family OE. $F_{2} .05 .04$, named Family 3.

The numbering of the different linkage groups (LG) was the same between the different families. When two groups were part of the same LG but not recognized as such in a family, they were labelled <a> and <b> (e.g. LG 4a, LG 4b). An LG identified in only one family was labelled as a $<$ supernumerary $>$ group (S).

\subsection{QTL analysis}

QTL mapping was performed independently for each of the $F_{2}$ families and for each studied phenotypes using the MapQTL ${ }^{\circledR} 5$ program (van Ooijen, 2004) on the newly constructed genetic linkage maps. Phenotypes were either qualitative for survival ( 0 : died; 1: survived) or quantitative for B. ostreae load (number of parasites per $\mathrm{mg}$ fresh tissue). For parasite load, contrasting phenotypes were studied to optimize the QTL detection, using the selective genotyping method (Lander and Botstein, 1989). Thus, only the extreme phenotypes were considered: "survived-uninfected" (sacrificed individuals with no parasite detected by PCR), and "died-infected" (dead individuals with at least $1.10^{5}$ parasites detected per $\mathrm{mg}$ of fresh tissue).

QTL detection was performed using the interval mapping method developed by Lander and Botstein (1989), scanning for QTLs every $1 \mathrm{cM}$ on the linkage map. The likelihood of the presence of a segregating QTL was determined using a LOD score, when its value exceeded the predefined significance threshold somewhere in a linkage group. The empirical distribution of this significance threshold of the LOD score was obtained from 1,000 permutations (Churchill and Doerge, 1994) over each 
linkage group and over all linkage groups (the whole linkage map). Several LOD thresholds were defined on a sliding scale $(P$-values $=0.001 ; 0.005 ; 0.01 ; 0.05$ and 0.10 ) and applied to the result of the interval mapping to estimate the significance of the QTLs. A QTL with a $P$-value $<0.10$ at the chromosome-wide level was considered as suggestive, and a QTL with a $P$-value $<0.05$ at the chromosome-wide level was considered as significant (Le Bras et al., 2011). For suggestive QTLs, genetic effects were not taken into account due to the non-significance of the test because the values could be over- or under-estimated. The estimated position of a QTL on the map was defined by the maximum value of the LOD score and the $95 \%$ confidence interval, using the one LOD drop-off method of Lander and Botstein (1989). The percentage of the variance explained by the QTL was estimated by the MapQTL5 program, using the formula: $100^{*}(\mathrm{HO}$ _var - var)/population_variance, where HO_var is the residual variance under the current null hypothesis and var is the residual variance after fitting the QTL (van Ooijen, 2004). The effect of each significant QTL was then defined as the proportion of the genetic variation observed in the segregating family that is explained by the QTL (Erickson et al., 2004). QTLs were classified into three categories according to their effect: 1-"large-effect": those with an effect greater than 15-20\%; 2-"moderate-effect": those with an effect between 1\% and 15-20\%; and 3- "weak-effect": those with an effect less than $1 \%$ (Manly \& Olson, 1999; Erickson et al., 2004).

\section{RESULTS}

\subsection{Genotyping success}

Overall, $80.5 \%$ of the SNPs (309 out of 384 markers) were successfully genotyped. Among these, 22, 41 and 24 SNPs were monomorphic for Families 1, 2 and 3, respectively, and were removed from the analysis. A total of $121(39.2 \%), 106$ (34.3\%) and 121 (39.2\%) SNP markers in Families 1, 2 and 3, respectively, were informative (i.e. polymorphic) and were kept for linkage mapping.

A total of 115,78 and $92 F_{2}$ oysters were successfully genotyped for Families 1, 2 and 3 , respectively.

\subsection{Genetic linkage mapping}


For Families 1, 2 and 3, 53.7\% (65 out of 121), 52.8\% (56 out of 106) and 48.8\% (59 out of 121) of the SNPs, respectively, were distorted from Mendelian segregation $(P$ value $<0.05$ ), and $78.5 \%, 72.6 \%$ and $69.4 \%$, respectively, after Bonferroni correction. All markers were used for mapping irrespective of their fitting to Mendelian segregation.

The Family 1 genetic linkage map was based on the 121 SNPs that were informative for this family. Among these, 117 markers were successfully positioned in a total of twelve groups, including two groups for LG 4 (LG 4a, LG 4b), two groups for LG 5 (LG 5a, LG 5b) and two groups for LG 9 (LG 9a, LG 9b), established with a LOD score between 4 and 10 . Considering the 9 linkage groups (joining groups <a> and $<b>$ ), the number of markers per linkage group varied from 5 to 29 . The average inter-marker distance ranged from $1.2 \mathrm{cM}$ (LG 1) to $5.8 \mathrm{cM}$ (LG 6), with an average spacing of $3.1 \mathrm{cM}$. The largest interval varied from $5.9 \mathrm{cM}$ (LG 4b) to $22.3 \mathrm{cM}$ (LG 5a) (Table 1, Table S1, Fig. S1). The observed map length was $275.15 \mathrm{cM}$, corresponding to an estimated genome length of $348.65 \mathrm{cM}$, and an observed genome coverage of $78.9 \%$. Non-Mendelian markers were not homogeneously distributed on the linkage map $\left(X^{2}=408.563\right.$, df $\left.=11, P<0.001\right)$ but tended to cluster in specific linkage groups. In four linkage groups (LG3, LG 4a, LG 8 and LG 9b) $100 \%$ of mapped markers were distorted, and in three linkage groups (LG 1, LG 4b and LG 7) from $62 \%$ to $86 \%$ of mapped markers were distorted.

The Family 2 genetic linkage map was based on the 106 SNPs that were informative for this family. Among these, 96 markers were successfully positioned in a total of thirteen linkage groups, including two groups for LG 4 (LG 4a and LG 4b), two groups for LG 5 (LG 5a and LG 5b), two groups for LG 8 (LG 8a and LG 8b) and one supernumerary group (S1), established with a LOD score between 4 and 10 . Considering the nine linkage groups (joining groups $<a>$ and $<b>$ ), the number of markers per linkage group varied from 2 to 21 . The average inter-marker distance ranged from $1.6 \mathrm{cM}$ (LG 9) to $8.7 \mathrm{cM}$ (LG 6a), with an average spacing of $3.9 \mathrm{cM}$. The largest interval varied from $2.3 \mathrm{cM}$ (LG 9) to $27.1 \mathrm{cM}$ (LG 2) (Table 1, Table S2, Fig. S2). The genetic linkage map coverage was $253.55 \mathrm{cM}$, corresponding to an estimated genome length of $355.19 \mathrm{cM}$, and an observed genome coverage of $71.4 \%$. Non-Mendelian markers were not homogeneously distributed on the linkage 
map $\left(X^{2}=301.793, d f=12, P<0.001\right)$ but tended to cluster in specific linkage groups. In seven linkage groups (LG 4a, LG4b, LG5a, LG 6, LG 8b, LG 9 and S1) $100 \%$ of mapped markers were distorted, and in two linkage groups (LG 1 and LG 7) from $50 \%$ to $67 \%$ of mapped markers were distorted.

The completed genetic map for Family 3, which improves on the previouslypublished map by Lallias et al. (2009), was based on a total of 293 successfully positioned genetic markers, consisting of 119 SNPs, 17 microsatellites and 157 AFLPs, in a total of ten linkage groups. The number of markers per linkage group varied from 8 (LG 9) to 54 (LG 1), and the average inter-position distance (informative distance between two closely situated but differing positions on the map, considering as "one" position when many markers are located at exactly the same position) ranged from $1.5 \mathrm{cM}$ (LG 1) to 5.1 (LG 9), with an average informative spacing of 3.0 cM. The largest interval varied from $6.2 \mathrm{cM}$ (LG 6) to $28.7 \mathrm{cM}$ (LG 3) (Table 1, Table S3, Fig. 1). The genetic linkage map coverage was $536.40 \mathrm{cM}$, corresponding to an estimated genome length of $580.42 \mathrm{cM}$, and an observed genome coverage of 92.4\%. Non-Mendelian SNP markers were not homogeneously distributed on the linkage map $\left(X^{2}=250.061, d f=9, P<0.001\right)$ but tended to cluster in specific linkage groups. In two linkage groups (LG 8 and LG 9) 100\% of SNPs mapped markers were distorted, and in two other linkage groups (LG 2 and LG 4 ) from $79 \%$ to $82 \%$ of SNPs mapped markers were distorted.

Comparing genetic maps between the three segregating families, nine homology groups were identified based on a total of 111 SNPs that were common between at least two of the three families (Table 1). Among them, 52 SNPs were shared by both Family 1 and Family 2. As shared SNPs represented less than $50 \%$ of the mapped SNPs for each family (respectively, $43 \%$ and $49 \%$ ) and as there was a large difference in the distance estimated between loci and no common order, a consensus map would have been particularly complex to build and interpret and was thus not constructed. In Family 1, Family 2 and the completed map of Family 3, 12 SNPs, 38 SNPs and 192 markers (18 SNPs, 17 microsatellites, 157 AFLPs), respectively, segregated exclusively in these families. No homology group was found in Families 1 and 2 for LG 10, or in Family 1 and the completed map for S1. Based on the linkage of several markers that were common between the different families but that were 
successfully mapped in only one (or two) of them, LG 4a and LG $4 \mathrm{~b}$ were grouped to give LG 4, LG 5a and LG 5b were grouped to give LG 5, LG $8 a$ and LG $8 b$ were grouped to give LG 8, and LG 9a and LG $9 b$ were grouped to give LG 9.

\subsection{QTL mapping}

No significant tank effects on mortalities of donor oysters were found between the different tanks of each family, either for Family $1\left(X^{2}=0.047, d f=2, P=0.977\right)$ or Family $2\left(X^{2}=1.570, d f=2, P=0.456\right)$.

During the cohabitation experiment, 73 and 64 recipient oysters died for Families 1 and 2 , respectively, but only 57 and 42 had tissues in sufficiently good condition to allow DNA typing and $B$. ostreae quantification. After DNA extraction, some samples ( 5 and 8 ) could not be used for further analysis because of low DNA quality.

Finally, the phenotypes of 115 recipient oysters from Family 1 (63 survived; 7 diedinfected; 45 died-uninfected) and 78 recipient oysters from Family 2 (44 survived; 34 died-infected; 0 died-uninfected) were studied to detect QTL for survival after contact with donor oysters. The interval mapping method revealed the existence of four significant $(P<0.05)$ and one suggestive $(P<0.10)$ QTL in Family 1 , and one significant and one suggestive QTL in Family 2 (Table 2, Fig. 2). The significant QTLs were distributed in three different linkage groups: LG 2 (Family 1, Family 2), LG 3 (Family 1) and LG 8 (2 QTLs in Family 1). On LG 2, there was an overlap between the QTL locations in the two families. For Family 1, the significant QTLs explained $15.2 \%, 10.6 \%, 9.7 \%$ and $8.8 \%$ of the genetic variation for survival after contact with donor oysters. For Family 2, the significant QTL explained $17.2 \%$ of the genetic variation for this trait.

For the two families, the suggestive QTL was distributed on the same linkage group: LG 1. Given the narrowness of the confidence interval for the suggestive QTL in Family 2, no common markers were located within the interval and only one marker was simultaneously associated with the suggestive QTL for the two families. Consequently, it is not possible to test the hypothesis of an overlap of the QTL locations between the two tested families.

Secondly, QTL were also detected for $B$. ostreae load. For Family 1, the mean $B$. 
ostreae load per mg of fresh tissue was $9.6 \times 10^{3}$ (ranging from 0 to $2.9 \times 10^{5}$ ) for dead individuals. For Family 2, the mean $B$. ostreae load per $\mathrm{mg}$ of fresh tissue was $1.4 \times 10^{2}$ (ranging from 0 to $1.9 \times 10^{3}$ ) for individuals that survived and $1.6 \times 10^{6}$ (ranged from $2.7 \times 10^{3}$ to $8.3 \times 10^{6}$ ) for individuals that died. Because many individuals $(96.1 \%)$ from Family 1 that died did not have a $B$. ostreae load above $1.10^{5}$ parasites per $\mathrm{mg}$ of fresh tissue, extreme phenotypes of parasite load were not available and parasite load has not been assessed for surviving individuals for this family. So, the detection of QTLs linked to parasite load was only performed in Family 2. For this second family, 15 individuals of phenotype "survived-uninfected" and 17 individuals of phenotype "died-infected" were used to detect QTLs for parasite load. Moreover, as quantitative values of parasite load were not normally distributed, the phenotypic data were transformed into qualitative binary data (Lallias et al., 2009).

The interval mapping method revealed the existence of one significant $(P<0.05)$ and two suggestive $(P<0.10)$ QTLs linked to parasite load (Table 2, Fig. 2). The significant QTL, located in LG 2, is the same as that detected for survival after contact with donor oysters, but it explained $22.1 \%$ of the genetic variation for this trait. The two suggestive QTLs were distributed in two different linkage groups: LG 1 and LG 6.

Overall, for both families, the QTL alleles linked to the "survived" phenotype originated from the selected grandparents (703-29 or L002-55), and the QTL allele linked to the "died" phenotype originating from the wild grandparents (W31 or W120). One exception was observed for Family 1 in LG 1 (snp_Contig25127_1757, Fig. 2). Also, for some loci it was not possible to identify the origin of the QTL alleles because of the heterozygosity of the grandparents.

\section{DISCUSSION}

\subsection{Genetic linkage mapping}

In the present study, two new genetic linkage maps were constructed for the European flat oyster $O$. edulis for use in the detection of QTLs for survival after contact with wild oysters injected with $B$. ostreae and in relation to parasite load. The set of 384 SNPs specifically developed on O. edulis by Lapègue et al. (2014) was applied for the first time. These molecular markers showed a relatively high level 
of segregation distortion in the two mapping families, but this was of a similar order of magnitude to those already reported in similar $F_{2}$ families of oyster species ( $O$. edulis, Lallias et al., 2007, 2009; C. gigas, Sauvage et al., 2010). Furthermore, as already observed in some oyster species (C. gigas: Li and Guo, 2004, O. edulis: Lallias et al., 2007, 2009), distorted markers tended to cluster in specific linkage groups on the new genetic linkage maps. The observation of clusters that differed between the families could reflect the proximity of potential deleterious genes in the LGs.

Segregation distortion is commonly observed in oyster species and bivalves in general (Launey and Hedgecock, 2001; Li and Guo, 2004; Lallias et al., 2009), where null alleles may account for a large part of this phenomenon. Furthermore segregation distortion in pair crosses of oyster species can be explained by a high genetic load (i.e. a large number of deleterious recessive mutations) in the genome (Bierne et al., 1998; Launey and Hedgecock, 2001). The extreme protein heterozygosity of marine bivalves has been hotly debated in the past, at the heart of the neutralist-selectionist controversy, but the question has never been answered definitively. Recently, a high load of segregating non-neutral amino-acid polymorphisms was suggested to contribute to high protein diversity in wild populations of $O$. edulis (Harrang et al., 2013).

Although the average marker spacing appeared smaller than that observed in previous studies on O. edulis (above 4 cM, Lallias et al., 2007, 2009), the estimated genome length appeared lower (about 550-575 cM) for an equivalent number of mapped markers. In order to make comparison possible with the two new genetic linkage maps, we added the set of 384 SNPs developed by Lapègue et al. (2014) to the map published by Lallias et al. (2009) This "completed" map showed a genome length very close to previous estimates for $O$. edulis (see above). Thereby, this study presents both the best estimate of the genome coverage (92.4\%) of the European flat oyster, and the largest number of molecular markers mapped on a single genetic linkage map for an oyster species ( $n=293$ ). Even so, with the availability of new transcriptomic assemblies for some oyster species and the recently sequenced genome of $C$. gigas (Zhang et al., 2012), this performance should soon be surpassed. For the moment, the completed map becomes the reference genetic linkage map for 
the European flat oyster.

Comparing this completed genetic linkage map with the new ones (Family 1 and Family 2, this study), a total of 353 different markers were successfully positioned on the three maps: 179 SNPs, 157 AFLPs and 17 microsatellites. The completed map consisted of 10 linkage groups, corresponding to the haploid number of chromosomes in the species (Thiriot-Quiévreux and Ayraud, 1982). However, only nine linkage groups were identified as homologous between the three different segregating families, and two other linkage groups were observed in only one of the families. In particular, the supernumerary group observed in Family 2 consisted of only two linked markers, which may in fact belong to LG 6 and fuse in other genetic backgrounds for which other SNPs could be mapped and exhibit new associations (E. Harrang, data not published). Within the homologous linkage groups, the order of mapped markers is relatively conserved. The variations observed could illustrate the different recombination rates of markers within each family. The present study thereby confirms the primary interest of comparing genetic linkage maps constructed for different genetic backgrounds.

\subsection{Comparative QTL mapping}

The present study aimed to estimate the diversity of QTLs where a response is noted to an experimental infection with the parasite responsible for bonamiosis, $B$. ostreae, in two segregating families of $O$. edulis. A total of seven QTLs linked to the phenotypes survived / died were identified in the two families. In the second family, the search for QTL regions linked to parasite load led to the detection of a new one. All these QTLs were located on a total of five different linkage groups, confirming the polygenic feature of the response to bonamiosis previously identified by Lallias et al. (2009). Two linkage groups were identical between the two families (LG 1 and LG 2) but, given that the rates of recombination between markers were specific to each reproductive event, and each breeding pair, mapped markers and marker order were not identical between family genetic linkage maps. Consequently, QTL regions were not positioned exactly at the same intervals, although these QTL regions might be identical, particularly for LG 2 where several markers were identified within the confidence interval of the QTL in the two segregating families. Even though only two 
families were analysed, with a relatively low number of individuals per family, some interesting features can be highlighted.

Interestingly, Family 1 is related to Family 3 . Indeed, the parental individuals $\left(F_{1}\right)$ belong to the same family produced from the same grandparents ( $F_{0}$ : W31 \& 703-29). Although the effect of a QTL is supposedly not the same in each family even if they share a common genetic background (Knott, 2005), it is also very interesting to compare the QTLs detected in each of these similar experiments. Indeed, if a QTL exists, it must necessarily segregate in more than one family (Knott, 2005), and therefore we should find common regions in homologous linkage groups. The five QTLs identified by Lallias et al. (2009) were located in LG 1, LG 3, LG 5 and LG 8 of the completed genetic linkage map of Family 3. Thus, one linkage group (LG 1) was simultaneously concerned in the detection of QTLs in the two newly tested families, and two linkage groups (LG 3 and LG 8) were simultaneously concerned in the related family (Family 1). Confidence intervals and markers associated with QTLs were not identical between the three families but the detection of QTL region(s) in these homologous linkage groups simultaneously in several families tends to confirm the potential of these suggestive regions.

For LG 3 and LG 8, a lack of common molecular markers between Families 1 and 3 prevented any conclusions from being drawn about whether there were one or more QTLs. It is thus not possible to make a deduction about the potential of one or several different or common QTLs between the families for these linkage groups. However, it appears that all of these QTLs were important in the response to bonamiosis. The reliability of their location still needs to be improved by increasing the number of families and number of animals tested per family.

The detection of the same QTL in several families depends on several other factors, such as the frequency of QTL alleles, proportion of the explained variance and density of the markers used for screening. Therefore, while finding the same QTL in several families is important for consistency, finding it in only one family can be explained by these factors, or a different genetic background, differing segregation over the three generations despite an identical genetic background (grandparents not coming from pure lines, case of related Family 1 and 3 ), the conditions of the 
experimental infection, or it is a false positive (type I error).

Another hypothesis is that QTLs detected in related families were associated with different responses of the oyster to the infection because the development of the infection might not be exactly the same in tested individuals, and they might be sampled at different points in the process of host response. Indeed, it has previously been shown that the expression of some immune related genes is variable over time (Morga et al., 2011b) and different QTLs were identified at different stages of development in cultivated rice (Yan et al., 1998). Thus, it is possible that, at a certain time during the infection, only some QTLs would be favourable and subject to selection and thus detectable due to the difference of allelic frequencies between the two phenotypes examined.

A last hypothesis to explain the differences in QTL detection is based on the low number of oysters analysed due to the experimental conditions, especially for Family 2. Although the power of detection of QTLs linked to parasite load was enhanced by the selective genotyping method (Lander and Botstein, 1989), results might have been subject to the Beavis effect $(\mathrm{Xu}, 2003)$. However, the concurrent detection of QTL regions in the same linkage groups in several families strongly supports our results, as it is the case for QTL related to summer mortality in Pacific oyster (Sauvage et al., 2010).

Furthermore, it is important to note that the same QTL with a large-effect was identified for the phenotypes "died" / "survived" and "died-infected" / "surviveduninfected". Thereby, this study confirms the proliferation of the parasite as the probable cause of mortality, despite the fact that it was not detected in some individuals. In the context of our experiment, a load greater than $1.10^{5}$ parasites per milligram of tissue could be a good indicator of the sensitivity of individuals to bonamiosis. According to Robert et al. (2009), this proportion corresponds to a light infection by $B$. ostreae. Despite the fact that this quantitative parameter is difficult to measure by biopsy, because it weakens individuals, it may be a good predictor of future mortalities. However, although molecular tools detect parasite DNA they do not confirm presence of viable pathogens and established infection (Robert et al., 2009).

Overall, apart from a few exceptions, QTL alleles linked to flat oyster sensitivity 
to B. ostreae (phenotypes "died" and "died-infected") were preferentially transmitted to the $F_{2}$ generation by the grandparent of wild origin. Similarly, QTL alleles linked to the response to bonamiosis (phenotypes "survived" and "survived uninfected") were preferentially transmitted by the grandparent from the selected line. These results tend to confirm the effectiveness of the selection of European flat oyster lines based on death or survival during experimental challenges to bonamiosis even if the use of markers linked to QTLs cannot yet be used to help selection at this stage.

Finally, the 21 SNPs identified as being significantly linked to QTLs correspond to genes that clustered into 7 main categories according to their putative biological function predicted by NCBI using GO (Gene Ontology) (Table 3). It is interesting to note that most of these genes $(24 \%)$ cluster in the "cell communication, membrane receptor and immune system" category. Furthermore, the confidence interval of some QTLs includes some genes previously shown to be involved in the response of the oyster to an infection with B. ostreae (Morga et al., 2011a, 2012). However, these SNPs may in no case be directly used to infer the genes involved in the mechanisms of resistance or sensitivity to bonamiosis. Indeed, the confidence intervals of the identified QTLs are relatively large $(0.5 \mathrm{cM}$ to $25 \mathrm{cM})$, and may contain several hundred genes, of which only a portion are involved in the response mechanisms. Thus, these genes are not necessarily related to immune response genes, but may participate in the regulation cascade of other genes directly involved in these mechanisms. However, they can still be considered as good candidates for transcriptomic analyses.

\section{Conclusions}

To summarize, we first improved and updated the previously published geneticlinkage map for the European flat oyster using a set of SNP markers. Secondly, we identified and confirmed, using two different oyster families, several regions of the European flat oyster genome that are associated (1) with the survival after contact with wild oysters injected with Bonamia ostreae and (2) with parasite load. We also detected, within the confidence intervals of these QTL regions, some previously predicted candidate genes differentially expressed during an infection with $B$. ostrea 
(Morga et al., 2011a, 2012). However, to improve the knowledge of the genetic architecture of the survival trait, it could be interesting to identify the genomic regions that are involved in the expression of these different candidate genes, and then to make a comparison between these eQTLs (expression Quantitative Trait Loci) and the QTL regions identified in the present study. Furthermore, in the future the localization of the QTL regions could be improved by the use of high-resolution linkage mapping, especially with RAD-Tag technology, as recently applied in the scallop Chlamys farreri (Jiao et al., 2014), another marine bivalve species. 


\section{ACKNOWLEDGEMENTS}

The authors wish to thank all members of staff of the Ifremer hatchery in La Tremblade for technical assistance with the production and rearing of the oysters, and for maintenance during the cohabitation challenge experiment. The authors thank Bruno Chollet for his help with specialised training in the $B$. ostreae purification method. This research was funded by the European Transnational SEAFARE project (Sustainable and Environmentally Friendly Aquaculture for the Atlantic Region of Europe - $\left.\mathrm{n}^{\circ} 2009-1 / 123\right)$, funded by the Atlantic Area Transnational Program (20072013). The authors also wish to thank Bureau de Traduction de I'Université de Brest (Helen McCombie) for English editing.

\section{REFERENCES}

Baud, J.P., Gerard, A., Naciri-Graven, Y., 1997. Comparative growth and mortality of Bonamia ostreae-resistant and wild flat oysters, Ostrea edulis, in an intensive system. I. First year of experiment. Marine Biology 130: 71-79.

Bédier, E., Baud, J.-P., Cochennec, N., Cornette, F., Gérard, A., Goyard, E., Joly, J.-P., Kopp, J., Langlade, A., Le Coguic, Y., Mazurié, J., Nourry, M., 2001. L'amélioration des performances de l'huître plate européenne Ostrea edulis par la sélection génétique. In: Journées Conchylicoles du Département Ressources Aquacoles. La Tremblade, Ifremer.

Bierne, N., Launey, S., Naciri-Graven, Y., Bonhomme, F., 1998. Early effect of inbreeding as revealed by microsatellite analyses on Ostrea edulis larvae. Genetics 148: 1893-1906.

Cahais, V., Gayral, P., Tsagkogeorga, G., Melo-Ferreira, J., Ballenghien, M., Weinert, L., Chiari, Y., Belkhir, K., Ranwez, V., Galtier, N., 2012. Referencefree transcriptome assembly in non-model animals next-generation sequencing data. Molecular Ecology Resources 12: 834-845.

Chakravarti, A., Lasher, L.K., Reefer, J.E., 1991. A maximum-likelihood method for estimating genome length using genetic-linkage data. Genetics 128: 175182.

Churchill, G.A., Doerge, R.W., 1994. Empirical threshold values for quantitative trait mapping. Genetics 138: 963-971. 
Cui, S., He, X., Fu, S., Meng, Q., Gai, J., Yu, D., 2008. Genetic dissection of the relationship of apparent biological yield and apparent harvest index with seed yield and yield related traits in soybean. Australian Journal of Agricultural Research 59: 86-93.

Culloty, S.C., Cronin, M.A., Mulcahy, M.F., 2001. An investigation into the relative resistance of Irish flat oysters Ostrea edulis L. to the parasite Bonamia ostreae (Pichot et al., 1980). Aquaculture 199: 229-244.

Dekkers, J.C.M., 2004. Commercial application of marker- and geneassisted selection in livestock: Strategies and lessons. Journal of Animal Science 82: E313-E328.

Erickson, D.L., Fenster, C.B., Stenoien, H.K., Price, D., 2004. Quantitative trait locus analyses and the study of evolutionary process. Molecular Ecology 13: 2505-2522.

FAO, 2011. Global Aquaculture Production: Quantities 1950-2011. www.fao.org/fishery/statistics/global-aquaculture-production/query.

Guo, X., Li, Q., Wang, Q., Kong, L., 2012. Genetic mapping and QTL analysis of growth-related traits in the Pacific oyster. Marine Biotechnology 14: 218226.

Harrang, E., Lapègue, S., Morga, B., Bierne, N., 2013. A high load of nonneutral amino-acid polymorphisms explains high protein diversity despite moderate effective population size in a marine bivalve with sweepstakes reproduction. G3: Genes Genomes Genetics 3: 333-341.

Jaziri, H., 1990. Variations génétiques et structuration biogéographique chez un bivalve marin: I'huître plate Ostrea edulis L.: Thèse de doctorat, Montpellier.

Jiao, W., Fu, X., Dou, J., Li, H., Su, H., Mao, J., Yu, Q., Zhang, L., Hu, X., Huang, X., Wang, Y., Wang, S., Bao, Z., 2014. High-resolution linkage and Quantitative Trait Locus mapping aided by genome survey sequencing: building up an integrative genomic framework for a bivalve mollusc. DNA Research 21: 85-101.

Knott, S.A., 2005. Regression-based quantitative trait loci mapping: robust, efficient and effective. Philosophical Transactions of the Royal Society B-Biological Sciences 360: 1435-1442.

Kosambi, D.D., 1944. The estimation of map distances from recombination 
values. Annals of Eugenics 12: 172-175.

Lallias, D., Beaumont, A.R., Haley, C.S., Boudry, P., Heurtebise, S., Lapègue, S., 2007. A first-generation genetic linkage map of the European flat oyster Ostrea edulis (L.) based on AFLP and microsatellite markers. Animal Genetics 38: 560-568.

Lallias, D., Arzul, I., Heurtebise, S., Ferrand, S., Chollet, B., Robert, M., Beaumont, A.R., Boudry, P., Morga, B., Lapègue, S., 2008. Bonamia ostreaeinduced mortalities in one-year old European flat oysters Ostrea edulis: experimental infection by cohabitation challenge. Aquatic Living Resources 21: 423-439.

Lallias, D., Gomez-Raya, L., Haley, C.S., Arzul, I., Heurtebise, S., Beaumont, A.R., Boudry, P., Lapègue, S., 2009. Combining two-stage testing and interval mapping strategies to detect QTL for resistance to bonamiosis in the European flat oyster Ostrea edulis. Marine Biotechnology 11: 570-584.

Lander, E.S., Botstein, D., 1989. Mapping mendelian factors underlying Quantitative Traits using RFLP linkage maps. Genetics 121: 185-199.

Lapègue, S., Harrang, E., Heurtebise, S., Flahauw, E., Donnadieu, C., Gayral, P., Ballenghien, M., Genestout, L., Barbotte, L., Mahla, R., Haffray, P., Klopp, C., 2014. Development of SNP genotyping arrays in two shellfish species. Molecular Ecology Resources, doi: 10.1111/1755-0998.12230.

Launey, S., Barre, M., Gerard, A., Naciri-Graven, Y., 2001. Population bottleneck and effective size in Bonamia ostreae-resistant populations of Ostrea edulis as inferred by microsatellite markers. Genetical Research 78: 259-270.

Launey, S., Hedgecock, D., 2001. High genetic load in the Pacific oyster Crassostrea gigas. Genetics 159: 255-265.

Le Bras, Y., Dechamp, N., Krieg, F., Filangi, O., Guyomard, R., Boussaha, M., Bovenhuis, H., Pottinger, T.G., Prunet, P., Le Roy, P., Quillet, E., 2011. Detection of QTL with effects on osmoregulation capacities in the rainbow trout (Oncorhynchus mykiss). Bmc Genetics 12: 46.

Li, H., Liu, X., Zhang, G., 2012. A consensus microsatellite-based linkage map for the hermaphroditic bay scallop (Argopecten irradians) and its application in size-related QTL analysis. PLoS ONE 7(10): e46926.

Li, L., Guo, X., 2004. AFLP-based genetic linkage maps of the Pacific oyster 
Crassostrea gigas Thunberg. Marine Biotechnology 6: 26-36.

Manly, K.F., Olson, J.M., 1999. Overview of QTL mapping software and introduction to map manager QT. Mammalian Genome 10: 327-334.

Martin, A.G., Gérard, A., Cochennec, N., Langlade, A., 1992. Selecting flat oysters, Ostrea edulis, for survival against the parasite Bonamia ostreae: assessment of the resistance of a first selected generation. In: Production, environment and quality, Bordeaux Aquaculture 1992.

Mialhe, E., Bachère, E., Chagot, D., Grizel, H., 1988. Isolation and purification of the protozoan Bonamia ostreae (Pichot et al., 1979), a parasite affecting the flat oyster Ostrea edulis L. Aquaculture 71: 293-299.

Morga, B., Arzul, I., Faury, N., Segarra, A., Chollet, B., Renault, T., 2011 a. Molecular responses of Ostrea edulis haemocytes to an in vitro infection with Bonamia ostreae. Developmental and Comparative Immunology 35: 323-333.

Morga, B., Renault, T., Faury, N., Chollet, B., Arzul, I., 2011b. Cellular and molecular responses of haemocytes from Ostrea edulis during in vitro infection by the parasite Bonamia ostreae. International Journal for Parasitology 41: 755-764.

Morga, B., Renault, T., Arzul, I., 2012. New insights in flat oyster Ostrea edulis resistance against the parasite Bonamia ostreae. Fish and Shellfish Immunology 32: 958-968.

Morton, N.E., 1955. Sequential tests for the detection of linkage. American journal of human genetics 7: 277-318.

Naciri-Graven, Y., Martin, A.G., Baud, J.P., Renault, T., Gerard, A., 1998. Selecting the flat oyster Ostrea edulis (L.) for survival when infected with the parasite Bonamia ostreae. Journal of Experimental Marine Biology and Ecology 224: 91-107.

Qin, Y., Liu, X., Zhang, H., Zhang, G., Guo, X., 2007. Genetic mapping of size-related quantitative trait loci (QTL) in the bay scallop (Argopecten irradians) using AFLP and microsatellite markers. Aquaculture 272: 281-290.

Ranson, G., 1967. Les espèces d'huîtres vivant actuellement dans le monde, définies par leurs coquilles larvaires ou prodissoconques. Etude des collections de quelques-uns des grands musées d'histoire naturelle. Revue des Travaux de I'Institut des Pêches Maritimes 31: 127-274.

Robert, M., Garcia, C., Chollet, B., Lopez-Flores, I., Ferrand, S., Francois, 
C., Joly, J.-P., Arzul, I., 2009. Molecular detection and quantification of the protozoan Bonamia ostreae in the flat oyster, Ostrea edulis. Molecular and Cellular Probes 23: 264-271.

Sauvage, C., Boudry, P., de Koning, D.-J., Haley, C.S., Heurtebise, S., Lapègue, S., 2010. QTL for resistance to summer mortality and OsHV-1 load in the Pacific oyster (Crassostrea gigas). Animal Genetics 41: 390-399.

Spelman, R.J., van Arendonk, J.A.M., 1997. Effect of inaccurate parameter estimates on genetic response to marker-assisted selection in an outbred population. Journal of Dairy Science 80: 3399-3410.

Thiriot-Quiévreux, C., Ayraud, N., 1982. Les caryotypes de quelques espèces de bivalves et de gastéropodes marins. Marine Biology 70: 165-172.

van Ooijen, J.W., 2004. MapQTL 5: Software for the mapping of quantitative trait loci in experimental populations. Wageningen, Netherlands: Plant Research International B.V. and Kyazma B.V.

van Ooijen, J.W., 2006. JoinMap 4: Software for the calculation of genetic linkage maps in experimental populations. Wageningen, Netherlands: Plant Research International B.V. and Kyazma B.V.

Vercaemer, B., Spence, K.R., Herbinger, C.M., Lapegue, S., Kenchington, E.L., 2006. Genetic diversity of the European oyster (Ostrea edulis L.) in Nova Scotia: Comparison with other parts of Canada, Maine and Europe and implications for broodstock management. Journal of Shellfish Research 25: 543-551.

Vignal, A., Milan, D., SanCristobal, M., Eggen, A., 2002. A review on SNP and other types of molecular markers and their use in animal genetics. Genetics Selection Evolution 34: 275-305.

Visscher, P.M., Thompson, R., Haley, C.S., 1996. Confidence intervals in QTL mapping by bootstrapping. Genetics 143: 1013-1020.

Xu, S., 2003. Theoretical basis of the Beavis effect. Genetics 165: 22592268.

Yan, J., Zhu, J., He, C., Benmoussa, M., Wu, P., 1998. Molecular dissection of developmental behavior of plant height in rice (Oryza sativa L.). Genetics 150: 1257-1265.

Yu, Z.N., Guo, X.M., 2006. Identification and mapping of disease resistance 
QTLs in the Eastern oyster, Crassostrea virginica Gmelin. Aquaculture 254: 160-170.

Zhan, A., Hu, J., Hu, X., Hui, M., Wang, M., Peng, W., Huang, X., Wang, S., Lu, W., Sun, C., Bao, Z., 2009. Construction of microsatellite-based linkage maps and identification of size-related quantitative trait loci for Zhikong scallop (Chlamys farreri). Animal Genetics 40: 821-31.

Zhang, G., Fang, X., Guo, X. et al., 2012. The oyster genome reveals stress adaptation and complexity of shell formation. Nature 490: 49-54. 


\section{FIGURE LEGENDS}

Fig. 1: Genetic linkage map of the European flat oyster Ostrea edulis, mapping Family 3 (Lallias et al., 2009) with the addition of 384 SNPs genotyped in 92 individuals. The new genetic linkage map consists of 119 SNPs, 17 microsatellites and 157 AFLPs mapped in ten linkage groups, for a total length of $536.4 \mathrm{cM}$.

Fig. 2: Comparative mapping of significant and suggestive QTLs linked to resistance or sensitivity to bonamiosis in the European flat oyster Ostrea edulis, for Families 1, 2 and 3 (completed map). Only linkage groups (LG) with significant or highly suggestive QTL in Families 1 or 2 are shown. In each LG, markers are indicated on the right, and absolute positions on the left (in Kosambi cM). Interval mapping results are shown for Families 1 and 2: the LOD score is plotted against the position (cM) along the LG. Solid lines represent QTL $F$ ratio values for the survival trait, whereas dotted lines represent QTL $F$ ratio values for the parasite load trait. Straight dotted lines represent the significance threshold at the chromosome-wide level. The confidence interval of each QTL region is shown by a dark line, and the most probable location of a QTL is indicated with an arrow. Each molecular marker shown in colour bounds the confidence interval or is part of a QTL region, and is common to several homologous linkage groups. For each family, markers linked to the QTL regions and their locations in the LG are indicated with dark blue boxes. The additive effect (R: resistance; $S$ : sensitivity), the significance threshold $\left(^{* *}: p<0.01 ;{ }^{* * *}: p<0.001\right)$ and the grandparent from which the allele at the QTL originated are presented. (A): one LG is compared between the three families. (B), (C) and (E): three LG are compared between two families. (D) One linkage group is presented in one family. 


\section{Fig. 1:}

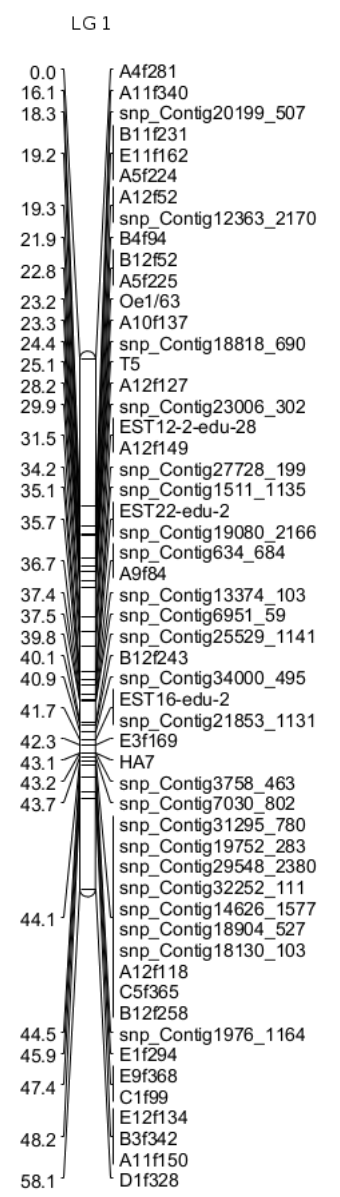
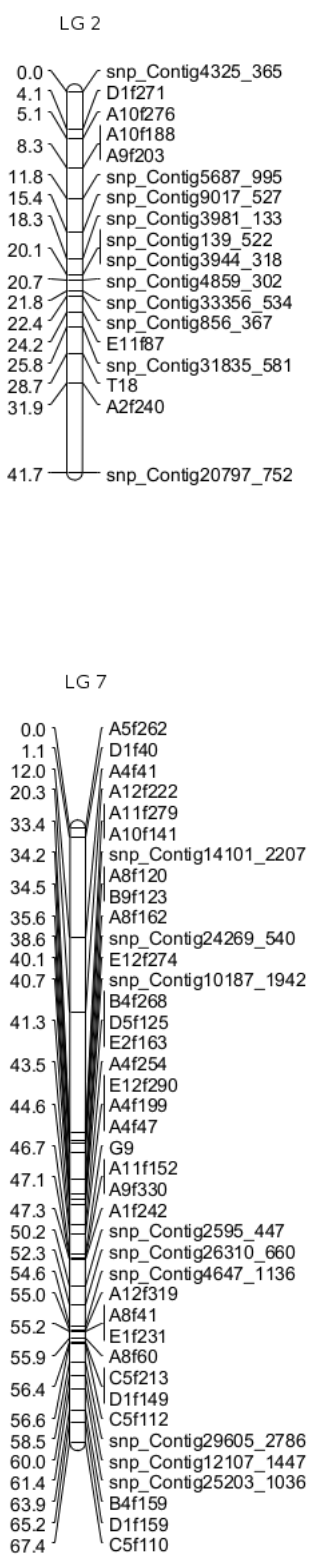
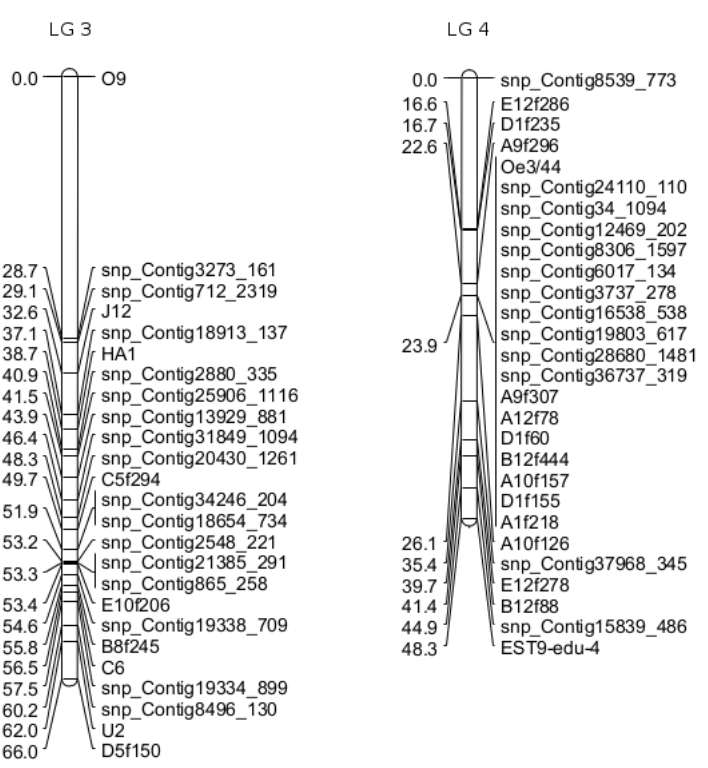

LG 8

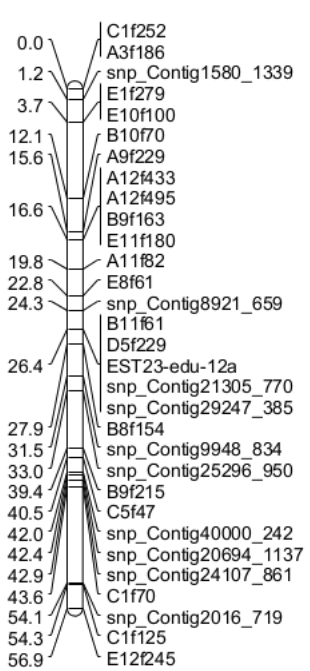

LG 5

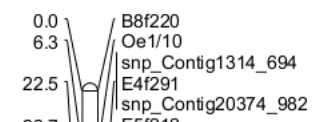

$\left.\begin{array}{l}22.7 \\ 23.7\end{array}\right]$ [ E5t212

24.6 || 0 Oe $1 / 47$

$\left.\begin{array}{l}26.1 \\ 26.8 \\ 27.1\end{array}\right]$ |

27.3
28.6 B Bff96 Contig1719-3569

$\left.\begin{array}{l}3.6 \\ 31.9 \\ 33.9\end{array}\right)=\left[\begin{array}{l}\text { HA21 } \\ \text { snp_Contig20497_105 } \\ \text { snp_Contig7988_1660 }\end{array}\right.$

${ }_{34.1}$ - $\begin{aligned} & \text { B12f478 } \\ & \text { snp_Contig1864 925 }\end{aligned}$

36.4 $\begin{aligned} & \text { Snp-Co } \\ & \text { E1f98 } \\ & \text { E5 } 5157\end{aligned}$

$\left.\begin{array}{l}39.7 \\ 42.0\end{array}\right]$ snp_Contig22302_2410

Isnp_Contig10006_701

48.6 A

$\left.\begin{array}{l}48.9 \\ 52.5\end{array}\right]$ A1f150

$55.3] \quad \begin{aligned} & \text { E4t87 } \\ & \text { A1f155 }\end{aligned}$
LG 6

$\left.\begin{array}{l}0.0 \\ 1.9\end{array}\right]\left[\begin{array}{l}\text { E5f115 } \\ \text { A } 11179 \\ \mathrm{A4f313} \\ \mathrm{A} 4152\end{array}\right.$

$\left.\begin{array}{l}4.2 \\ 5.1\end{array}\right)=U\left(\begin{array}{l}A 1152 \\ \text { Aff93 } \\ \text { Aft1 }\end{array}\right.$

7.1 ) _ snp_Contig9255 55

10.7) $=$ E1219187

14.0 $=\left(\begin{array}{l}\mathrm{A} 10 \mathrm{C} 140 \\ \mathrm{D} 1 \mathrm{f171}\end{array}\right.$

snp_Contig1963 1003

16.4 被

18.5. [ snp_Contit10292_3622 25.5 snp-Contig25211_263

29.4 佩 Esf123

$\left.\begin{array}{l}29.4 \\ 29.9\end{array}\right]-\begin{aligned} & \text { snp_Contig22142_194 } \\ & \text { Bff93 } \\ & \text { snp_Contig42545_446 }\end{aligned}$

36.0 X

39.7 _ snp_Contig38021_913

44.7 A10f139

47.8 | lan_Contig32322_156

48.6 [ Snf Contig3113_10

49.3 snp_Contig4827_70
LG 9

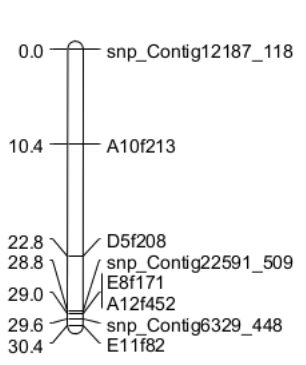

LG 10

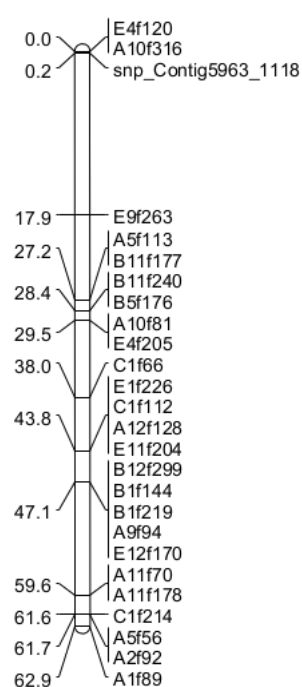


Fig. 2:

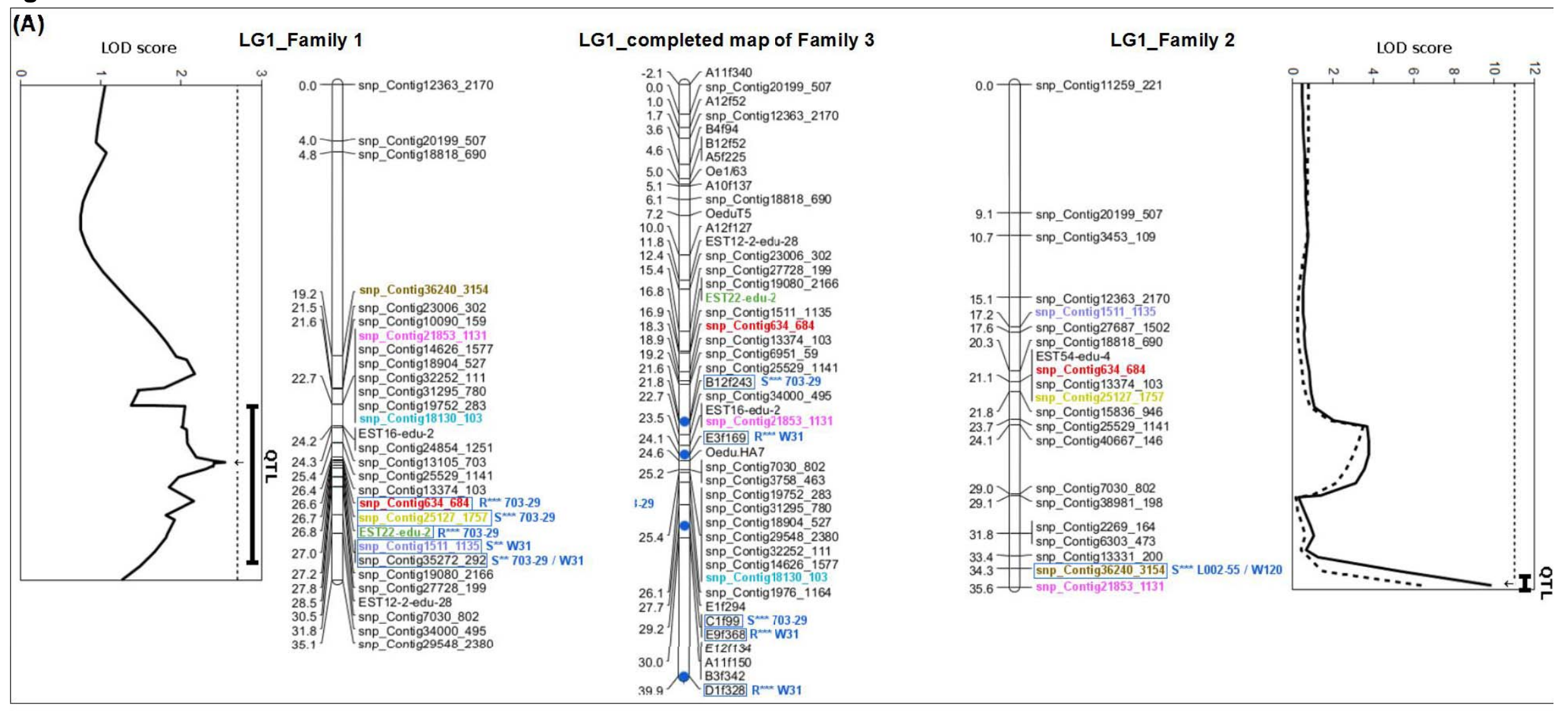


Fig. 2 (end):

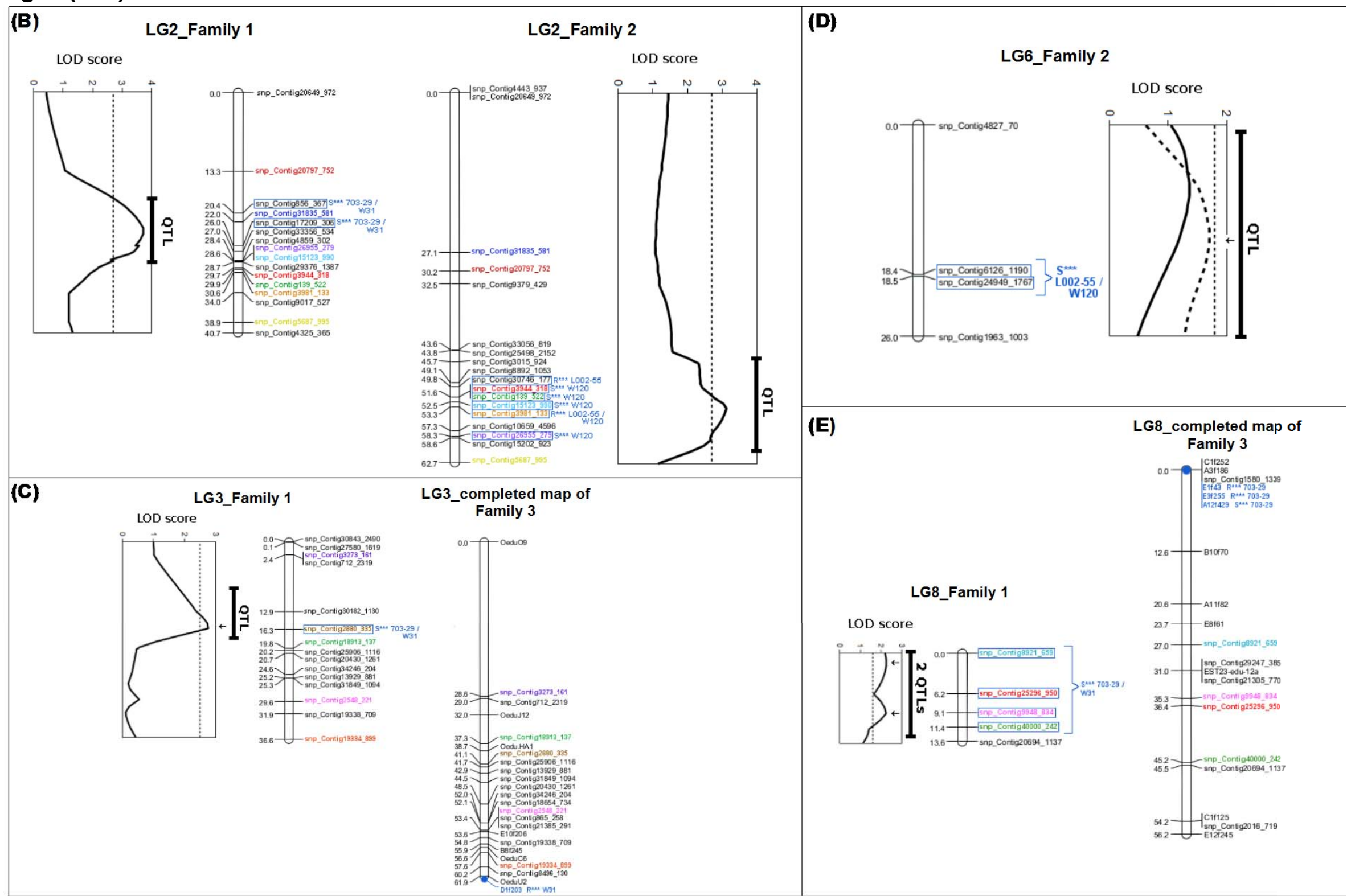


Table 1: Statistics of homology between linkage groups for Families 1, 2 and 3.

\begin{tabular}{|c|c|c|c|c|c|c|c|c|c|c|c|c|c|}
\hline \multirow[b]{2}{*}{$\begin{array}{l}\text { Linkage } \\
\text { group } \\
\text { (LG) }\end{array}$} & \multirow[b]{2}{*}{$\begin{array}{l}\text { Common } \\
\text { markers* }\end{array}$} & \multicolumn{4}{|l|}{ Family 1} & \multicolumn{4}{|l|}{ Family 2} & \multicolumn{4}{|c|}{ Improved map of Family 3} \\
\hline & & $\begin{array}{l}\text { No. of } \\
\text { mapped } \\
\text { markers }\end{array}$ & $\begin{array}{l}\text { Length } \\
\text { (cM) }\end{array}$ & $\begin{array}{l}\text { Average } \\
\text { spacing } \\
\text { (cM) }\end{array}$ & $\begin{array}{l}\text { Largest } \\
\text { interval } \\
(\mathrm{cM})\end{array}$ & $\begin{array}{l}\text { No. of } \\
\text { mapped } \\
\text { markers }\end{array}$ & $\begin{array}{l}\text { Length } \\
\text { (cM) }\end{array}$ & $\begin{array}{l}\text { Average } \\
\text { spacing } \\
\text { (cM) }\end{array}$ & $\begin{array}{l}\text { Largest } \\
\text { interval } \\
\text { (cM) }\end{array}$ & $\begin{array}{l}\text { No. of } \\
\text { mapped } \\
\text { markers }\end{array}$ & $\begin{array}{l}\text { Length } \\
\text { (cM) }\end{array}$ & $\begin{array}{l}\text { Average } \\
\text { spacing } \\
\text { (cM) }\end{array}$ & $\begin{array}{l}\text { Largest } \\
\text { interval } \\
(\mathrm{cM})\end{array}$ \\
\hline LG 1 & $25(0-0)$ & $29(4)$ & 35.10 & 1.25 & 14.40 & $21(10)$ & 35.60 & 1.78 & 9.10 & $54(31)$ & 58.12 & 1.10 & 16.12 \\
\hline LG 2 & $14(0-0)$ & $16(2)$ & 40.69 & 2.71 & 13.32 & $18(9)$ & 62.70 & 3.69 & 27.10 & $18(7)$ & 41.66 & 2.45 & 9.75 \\
\hline LG 3 & $16(0-0)$ & $15(2)$ & 36.65 & 2.62 & 10.43 & $13(4)$ & 41.20 & 3.44 & 18.10 & $25(10)$ & 65.98 & 2.75 & 28.74 \\
\hline LG 4a & \multirow{2}{*}{$15(0-0)$} & $12(0)$ & 0.0 & 0.0 & 0.0 & $13(3)$ & 0 & 0 & 0 & $28(14)$ & 48.30 & 1.79 & 16.60 \\
\hline$L G 4 b$ & & $3(0)$ & 9.03 & 4.52 & 5.87 & $2(0)$ & 7.86 & 7.86 & 7.86 & & & & \\
\hline LG 5a & \multirow{2}{*}{$15(1-3)$} & $0(0)$ & 44.72 & 4.97 & 22.28 & $7(1)$ & 19.20 & 3.21 & 10.10 & $32(20)$ & 55.35 & 1.79 & 16.15 \\
\hline LG $5 b$ & & $5(1)$ & 19.80 & 4.95 & 14.48 & $2(2)$ & 4.01 & 4.01 & 4.01 & & & & \\
\hline LG 6 & $11(0-0)$ & $11(1)$ & 51.80 & 5.76 & 15.70 & $4(1)$ & 26.00 & 8.67 & 18.45 & $31(20)$ & 49.33 & 1.64 & 6.20 \\
\hline LG 7 & $7(0-1)$ & $7(0)$ & 19.92 & 3.32 & 9.35 & $6(2)$ & 39.80 & 7.95 & 11.26 & $40(33)$ & 67.38 & 1.73 & 13.07 \\
\hline LG $8 \mathbf{a}$ & \multirow{2}{*}{$6(0-2)$} & $5(0)$ & 13.60 & 3.40 & 6.22 & $3(0)$ & 10.75 & 5.37 & 7.45 & $31(25)$ & 56.88 & 1.90 & 10.50 \\
\hline LG 8b & & & & & & $2(1)$ & 3.27 & 3.27 & 3.27 & & & & \\
\hline LG 9a & \multirow{2}{*}{$2(2-0)$} & $2(2)$ & 2.04 & 2.04 & 2.04 & $3(3)$ & 3.17 & 1.58 & 2.29 & $8(6)$ & 30.50 & 4.34 & 12.40 \\
\hline LG 9b & & $2(0)$ & 1.79 & 1.79 & 1.79 & & & & & & & & \\
\hline LG 10 & $0(0-0)$ & - & - & - & - & - & - & - & - & $26(26)$ & 62.90 & 2.52 & 17.65 \\
\hline S1 & $0(0-0)$ & - & - & - & - & $2(2)$ & 0.0 & 0.0 & 0.0 & - & - & - & - \\
\hline$\overline{\text { Total }}$ & $111(3-6)$ & $117(12)$ & 275.2 & - & - & $96(38)$ & 253.5 & - & - & $293(192)$ & 536.4 & - & - \\
\hline Mean & - & - & - & 3.1 & 9.7 & - & - & 3.9 & 9.2 & - & - & 2.2 & 14.7 \\
\hline
\end{tabular}

* Common markers are presented as: $a(b-c)$ where a: number of markers common to at least two of the three families; b: number of markers that were successfully positioned in only one family and linked to the same linkage group in another family but not mapped; c: number of markers that were successfully positioned in two families and linked to the same linkage group in the third family but not mapped. For each family, the number of mapped markers segregating specifically in this family is indicated in brackets. 
Table 2: Main characteristics of QTLs for survival after contact with wild oysters injected with Bonamia ostreae and in relation to parasite load, detected with Interval Mapping in two segregating families of the European flat oyster Ostrea edulis tested by experimental infection.

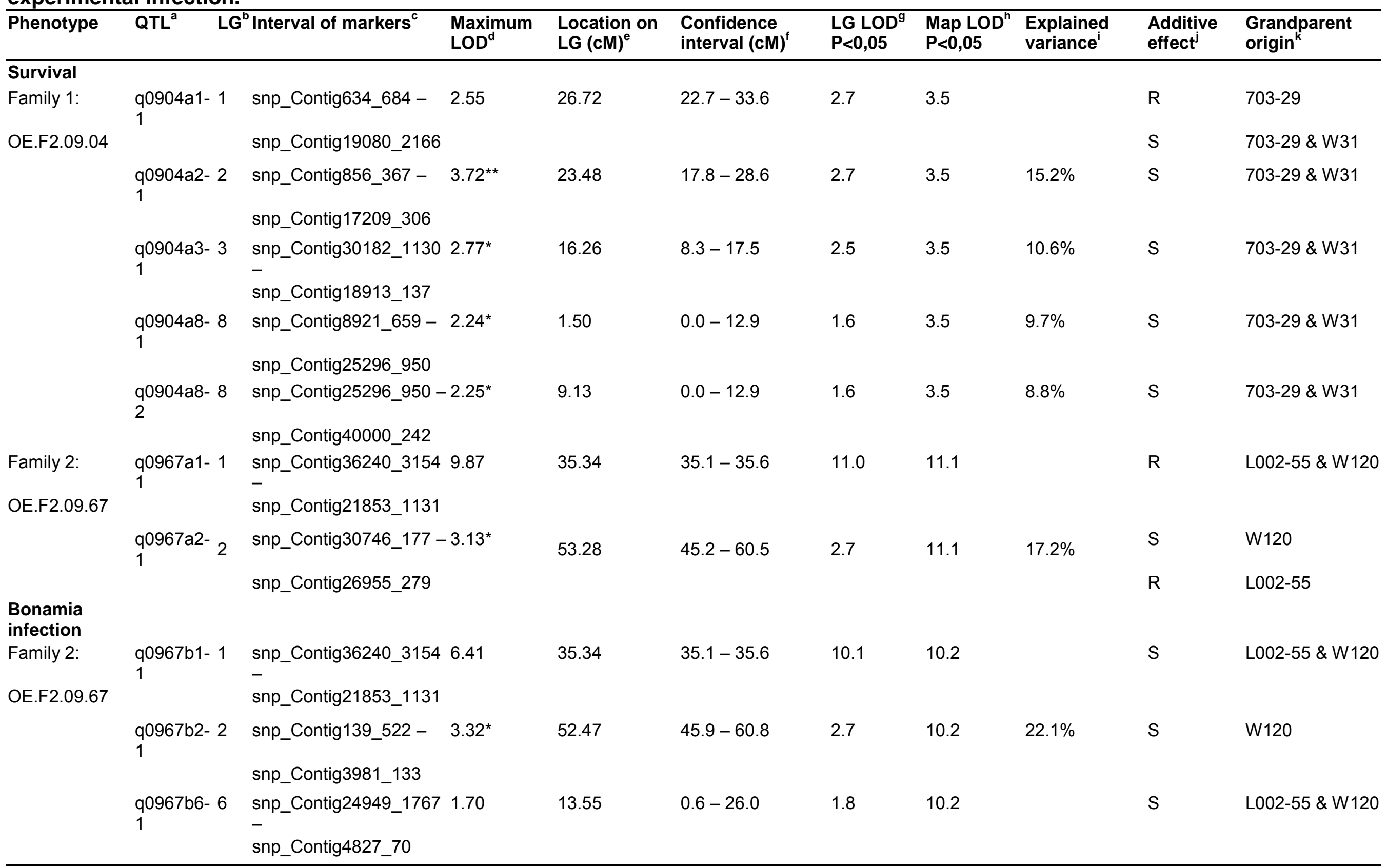


${ }^{a}$ Name of the QTL adapted from Cui et al. (2008): letter <q> followed by an abbreviation of the name of the family (0904 or 0967), followed by an <a> for the phenotype "survived" or $<b>$ for the phenotype "Bonamia infected", then the number of the linkage group, and finally the number of the QTL affecting this phenotype in the linkage group.

${ }^{b}$ Linkage group (LG) in which the QTL is mapped.

${ }^{\mathrm{c}}$ Interval of markers between which the QTL is mapped.

${ }^{d}$ Maximum LOD score and level of significance (no indication: $P \approx 0.10 ;{ }^{*}: P<0.05 ;{ }^{* *}: P<0.01$ ).

${ }^{\mathrm{e}}$ Best estimate of the location of the QTL in each LG.

${ }^{f}$ Confidence interval of the location of the QTL in each LG.

${ }^{g}$ LOD score at $P<0.05$ obtained after 1000 iterations by the permutation test (Churchill and Doerge, 1994), and corresponding to the significance level to be applied to $L G$ for the detection of QTL.

${ }^{\mathrm{h}}$ LOD score at $\mathrm{P}<0.05$ of the global genetic linkage map obtained after 1000 iterations by the permutation test (Churchill and Doerge, 1994).

' Percentage of total phenotypic variance explained by the detected QTL. The values are only given for QTL with LOD score exceeding the threshold of significance of the LG.

jEstimate of the phenotypic effect of the QTL: R for resistance (phenotype "survived" or "survived-uninfected"); S for sensitivity (phenotype "died" or "died-infected").

${ }^{k}$ Grandparental origin of the QTL allele. 
Table 3: Characteristics of the SNPs located in the confidence interval or linked to QTL for survival after contact with wild oysters injected with Bonamia ostreae and in relation to parasite load in two segregating families of the European flat oyster Ostrea edulis tested by experimental infection.

\begin{tabular}{|c|c|c|c|c|c|c|}
\hline Locus & \multicolumn{3}{|c|}{$\begin{array}{l}\text { LG Linked Homologous gene } \\
\text { to QTL }\end{array}$} & \multirow[t]{2}{*}{$\begin{array}{l}\text { BLAST } \\
\text { species }\end{array}$} & \multirow[t]{2}{*}{$\begin{array}{l}\text { Accession } \\
\text { number of } \\
\text { the gene }\end{array}$} & \multirow[t]{2}{*}{$\begin{array}{l}\text { Putative } \\
\text { biological } \\
\text { function }\end{array}$} \\
\hline \multicolumn{4}{|c|}{ Located into the confidence interval of the QTL } & & & \\
\hline EST22-edu-2 & 1 & $* * *$ & Ribosomal protein L3 & $\begin{array}{l}\text { Ostrea } \\
\text { edulis }\end{array}$ & JN680829 & Ribosomal \\
\hline snp_Contig36240_3154 & & $* * *$ & $\begin{array}{l}\text { Ankyrin repeat } \\
\text { domain-containing } \\
\text { protein } 17\end{array}$ & $\begin{array}{l}\text { Crassostrea } \\
\text { gigas }\end{array}$ & EKC23980 & $\begin{array}{l}\text { Cells } \\
\text { communication, } \\
\text { membrane } \\
\text { receptor, immune } \\
\text { system }\end{array}$ \\
\hline snp_Contig25127_1757 & & $* * *$ & $\begin{array}{l}\text { Guanine nucleotide- } \\
\text { binding protein } \mathrm{G}(\mathrm{o}) \\
\text { subunit alpha }\end{array}$ & $\begin{array}{l}\text { Crassostrea } \\
\text { gigas }\end{array}$ & EKC28055 & $\begin{array}{l}\text { Cells } \\
\text { communication, } \\
\text { membrane } \\
\text { receptor, immune } \\
\text { system }\end{array}$ \\
\hline snp_Contig634_684 & 1 & *** & $\begin{array}{l}\text { Thioredoxin domain- } \\
\text { containing protein } 12\end{array}$ & \multicolumn{2}{|c|}{$\begin{array}{l}\text { Crassostrea EKC27271 } \\
\text { gigas }\end{array}$} & $\begin{array}{l}\text { Detoxyfication, } \\
\text { stress protein }\end{array}$ \\
\hline snp_Contig1511_1135 & 1 & $* *$ & F-box only protein 4 & \multicolumn{2}{|c|}{$\begin{array}{l}\text { Crassostrea EKC18204 } \\
\text { gigas }\end{array}$} & $\begin{array}{l}\text { Cell cycle, DNA } \\
\text { repair, protein } \\
\text { regulation and } \\
\text { transcription }\end{array}$ \\
\hline snp_Contig35272_292 & 1 & ** & Hypothetical protein & N.A. & N.A. & Unknown fonction \\
\hline EST12-2-edu-28 & 1 & NS & $\begin{array}{l}\text { short-chain } \\
\text { dehydrogenase }\end{array}$ & $\begin{array}{l}\text { Ostrea } \\
\text { edulis }\end{array}$ & JN680824 & Respiratory chain \\
\hline snp_Contig139_522 & 2 & *** & $\begin{array}{l}\mathrm{FH} 1 / \mathrm{FH} 2 \text { domain- } \\
\text { containing protein } 3\end{array}$ & \multicolumn{2}{|c|}{$\begin{array}{l}\text { Crassostrea EKC } 35959 \\
\text { gigas }\end{array}$} & Cytoskeleton \\
\hline snp_Contig26955_279 & 2 & *** & $\begin{array}{l}\text { Myotubularin-related } \\
\text { protein } 4\end{array}$ & \multirow{2}{*}{\multicolumn{2}{|c|}{$\begin{array}{l}\text { Crassostrea EKC } 42140 \\
\text { gigas } \\
\text { Crassostrea EKC } 38956 \\
\text { gigas }\end{array}$}} & Metabolism \\
\hline snp_Contig3981_133 & 2 & *** & $\begin{array}{l}\text { Paired box pox-meso } \\
\text { protein }\end{array}$ & & & $\begin{array}{l}\text { Cell cycle, DNA } \\
\text { repair, protein } \\
\text { regulation and } \\
\text { transcription }\end{array}$ \\
\hline snp_Contig17209_306 & 2 & *** & $\begin{array}{l}\text { Tetratricopeptide } \\
\text { repeat protein } 17\end{array}$ & \multicolumn{2}{|c|}{$\begin{array}{l}\text { Crassostrea EKC24151 } \\
\text { gigas }\end{array}$} & Unknown fonction \\
\hline snp_Contig856_367 & 2 & *** & $\begin{array}{l}\text { Tripartite motif- } \\
\text { containing protein }\end{array}$ & \multicolumn{2}{|c|}{$\begin{array}{l}\text { Crassostrea EKC } 33533 \\
\text { gigas }\end{array}$} & $\begin{array}{l}\text { Cells } \\
\text { communication, } \\
\text { membrane } \\
\text { receptor, immune } \\
\text { system }\end{array}$ \\
\hline snp_Contig30746_177 & 2 & $* * *$ & Hypothetical protein & \multicolumn{2}{|c|}{$\begin{array}{l}\text { Crassostrea EKC41401 } \\
\text { gigas }\end{array}$} & Unknown fonction \\
\hline snp_Contig3944_318 & 2 & *** & Hypothetical protein & \multicolumn{2}{|c|}{$\begin{array}{l}\text { Crassostrea EKC } 39636 \\
\text { gigas }\end{array}$} & Unknown fonction \\
\hline snp_Contig15123_990 & 2 & $* * *$ & Hypothetical protein & N.A. & N.A. & Unknown fonction \\
\hline snp_Contig2880_335 & 3 & $* * *$ & Hypothetical protein & N.A. & N.A. & Unknown fonction \\
\hline
\end{tabular}




\begin{tabular}{|c|c|c|c|c|c|c|}
\hline & \multirow{3}{*}{${ }^{* * *}$} & \multirow{3}{*}{$\begin{array}{l}\text { 1-phosphatidylinositol- } \\
4,5 \text {-bisphosphate } \\
\text { phosphodiesterase } \\
\text { delta-1 } \\
\text { Hypothetical protein }\end{array}$} & \multirow{2}{*}{\multicolumn{2}{|c|}{$\begin{array}{l}\text { Crassostrea EKC } 40084 \\
\text { gigas }\end{array}$}} & \multirow[b]{2}{*}{ Metabolism } \\
\hline snp_Contig24949_1767 & & & & & & \\
\hline snp_Contig6126_1190 & 6 & & & N.A. & N.A. & Unknown fonction \\
\hline snp_Contig40000_242 & 8 & $* * *$ & Afadin & $\begin{array}{l}\text { Crassostrea } \\
\text { gigas }\end{array}$ & EKC42518 & $\begin{array}{l}\text { Cells } \\
\text { communication, } \\
\text { membrane } \\
\text { receptor, immune } \\
\text { system }\end{array}$ \\
\hline snp_Contig25296_950 & 8 & *** & Toll-like receptor 1 & $\begin{array}{l}\text { Crassostrea } \\
\text { gigas }\end{array}$ & EKC32484 & $\begin{array}{l}\text { Cells } \\
\text { communication, } \\
\text { membrane } \\
\text { receptor, immune } \\
\text { system }\end{array}$ \\
\hline snp_Contig8921_659 & 8 & $* * *$ & $\begin{array}{l}\text { Trithorax group protein } \\
\text { osa }\end{array}$ & $\begin{array}{l}\text { Crassostrea } \\
\text { gigas }\end{array}$ & EKC20059 & $\begin{array}{l}\text { Cell cycle, DNA } \\
\text { repair, protein } \\
\text { regulation and } \\
\text { transcription }\end{array}$ \\
\hline snp_Contig9948_834 & 8 & $* * *$ & Hypothetical protein & N.A. & N.A. & Unknown fonction \\
\hline \multicolumn{7}{|c|}{ Potentially located in the confidence interval of the QTL } \\
\hline EST54-edu-4 & 1 & NS & $\begin{array}{l}\text { cAMP-responsive } \\
\text { element binding } \\
\text { protein }\end{array}$ & $\begin{array}{l}\text { Ostrea } \\
\text { edulis }\end{array}$ & JN680843 & $\begin{array}{l}\text { Cells } \\
\text { communication, } \\
\text { membrane } \\
\text { receptor, immune } \\
\text { system }\end{array}$ \\
\hline EST23-edu-12a & 8 & NS & $\begin{array}{l}\text { Tyrosyl-tRNA } \\
\text { synthetase }\end{array}$ & $\begin{array}{l}\text { Ostrea } \\
\text { edulis }\end{array}$ & JN680830 & $\begin{array}{l}\text { Cell cycle, DNA } \\
\text { repair, protein } \\
\text { regulation and } \\
\text { transcription }\end{array}$ \\
\hline
\end{tabular}

NS: not significant.

**: $P<0.005$.

$* * *: P<0.001$.

N.A.: not available. 